https://doi.org/10.52058/2708-7530-2021-6(12)-176-183

Чень Сюй здобувач вищої освіти ступеня доктора філософії Міжрегіональної Академії управління персоналом, 03039, м. Київ, вул. Фрометівська, 2, тел.: 86(15) 373-560-285, e-mail: xingshangyoudao@163.com, https://orcid.org/0000-0002-1759-9940

\title{
ОГЛЯД ДИСКУРСНОГО ПОЛЯ ПРОБЛЕМАТИКИ ФОРМУВАННЯ ДЕРЖАВНОЇ ЕКОЛОГІЧНОЇ ПОЛІТИКИ
}

Анотація. У статті відмічено, що нинішній етап розвитку сучасного суспільства можна охарактеризувати значним погіршенням стану довкілля, порушенням нормального водного балансу на планеті, виснаженням багатьох природних ресурсів, таких необхідних для життя людства, та збільшенням кількості природних катастроф та катаклізмів. У такому ракурсі, здійснення охоронної функції довкілля та забезпечення відновлення його ресурсів, збереження генофонду нашої держави, підтримка перспективного розвитку усіх сфер життєдіяльності та соціально-економічного розвитку держави, в цілому, виступають пріоритетними шляхами реалізації екологічної політики держави.

Визначено, що міждисциплінарність як специфічна особливість питань державної політики у сфері захисту довкілля визначає наявність у різних наукових напрямах (економічному, правовому, соціологічному та інших) широкого кола досліджених питань, що, у такому ракурсі, дає змогу зрозуміти природу екологічної політики та основних принципів іiі успішної реалізації

Доведено, що для формування адекватної екологічної культури важливо впливати на ціннісні орієнтації суспільства, популяризувати знання про екологію у різних іiі аспектах та пропонувати напрями вдосконалення природоохоронної діяльності держави.

Також, відмічено, що у процесі вивчення політичного виміру вирішення екологічних проблем, науковцями визначено ключові цілі та концепцію реалізації національної екологічної політики, а, також, конкретні засоби для iї вироблення, та окреслено основні проблеми на шляху до їх ефективного впровадження у життя. $\mathrm{y}$ наукових доробках деяких науковців запропоновано авторське бачення щодо застосування методологічних інструментів 3 метою оцінювання процесів реалізації екологічної політики держави за критеріями якості, що дозволить встановити рівень ефективності iii впровадження на даний момент часу. У такому концепті розглядається конкретний стан навколишнього середовища, який би задовольняв потреби суспільства (як біологічні, так і соціальні). 
Ключові слова: державна екологічна політика, стан навколишнього середовища, природа екологічної політики, соціально-економічний розвиток держави, доробки науковців.

Chen Xu Higher education seeker of th Doctor of Philosophy of the Interregional Academy of Personnel Management, 03039, Kyiv, st. Frometivska, 2, tel.: $86 \quad$ (15) 373-560-285, e-mail: xingshangyoudao@ 163.com, https://orcid.org/0000-0002-1759-9940

\title{
OVERVIEW OF THE DISCOURSE FIELD OF PROBLEMS OF FORMATION OF THE STATE ENVIRONMENTAL POLICY
}

\begin{abstract}
The article notes that the current stage of development of modern society can be characterized by a significant deterioration of the environment, disruption of the normal water balance on the planet, depletion of many natural resources, so necessary for human life, and increasing natural disasters and cataclysms. In this perspective, the implementation of the environmental protection function and ensuring the restoration of its resources, preserving the gene pool of our state, supporting the long-term development of all spheres of life and socioeconomic development of the state, in general, are priority ways to implement environmental policy.
\end{abstract}

It is determined that interdisciplinarity as a specific feature of state policy in the field of environmental protection determines the presence in various scientific areas (economic, legal, sociological and others) of a wide range of research issues, which, in this perspective, allows to understand the nature of environmental policy and its basic principles. successful implementation

It is proved that for the formation of adequate ecological culture it is important to influence the value orientations of society, to popularize knowledge about ecology in its various aspects and to offer directions for improving the environmental activities of the state.

It was also noted that in the process of studying the political dimension of solving environmental problems, scientists identified key goals and concepts of national environmental policy, as well as specific tools for its development, and outlined the main problems on the way to their effective implementation. The scientific achievements of some scientists offer an author's vision for the use of methodological tools to assess the implementation of environmental policy of the state by quality criteria, which will establish the level of effectiveness of its implementation at this time. This concept considers a specific state of the environment that would meet the needs of society (both biological and social).

Keywords: state ecological policy, state of environment, nature of ecological policy, social and economic development of the state, achievements of scientists.

Постановка проблеми. Нинішній етап розвитку сучасного суспільства можна охарактеризувати значним погіршенням стану довкілля, порушенням нормального водного балансу на планеті, виснаженням багатьох природних ресурсів, таких необхідних для життя людства, та збільшенням кількості 
природних катастроф та катаклізмів. У такому ракурсі, здійснення охоронної функції довкілля та забезпечення відновлення його ресурсів, збереження генофонду нашої держави, підтримка перспективного розвитку усіх сфер життєдіяльності та соціально-економічного розвитку держави, в цілому, виступають пріоритетними шляхами реалізації екологічної політики держави.

Особливої ваги, у такому контексті, для України набуває реалізація оптимальної та адекватної екологічної політики, зважаючи на значну роль рівня якості життя населення та стану навколишнього середовища у функціонуванні будь-якої держави у процесах розвитку різноманітних сфер життєдіяльності людей та національно-культурного відродження нації, a, також, враховуючи перспективні напрями розвитку держави та наповнення іiі інтелектуального та ресурсного потенціалів [1].

Аналіз останніх досліджень і публікацій. Проблематику екологічної сфери розглядала велика кількість вітчизняних авторів, зокрема, виокремлено наступні напрями досліджень:

- нормативно-правове забезпечення процесів розроблення та реалізації державної екологічної політики (В. Андрейцев, А. Гулієв, В. Дьомкін, Ю. Сгоров, В. Костицький, Ж. Сіднєва, Ю. Шевчук та інші);

- визначення основних питань підтримки сталого розвитку нашої держави та перспективних напрямів розвитку сфери екології (А. Бардак, Л. Гринів, М. Орлов, А. Полешко, А. Шапар, Л. Шостак та інші);

- здійснення аналізу різних аспектів реалізації політики держави у сфері захисту довкілля, зокрема, організаційних, правових, економічних тощо (А. Андрусевич, Н. Андрусевич, В. Волинець, В.Глуха, Л. Жарова, Г. Марушевський, А. Надежденко, Н. Чечетата інші) [2].

Необхідно зазначити, що у зарубіжній науці, також, досить детально розкрито питання реалізації державної політики у сфері захисту довкілля. Так, дослідження різних аспектів забезпечення екологічних прав та вироблення природоохоронної політики держави було здійснено настпуними науковцями: В. Городинська, Г. Косов, С. Кочеткова, І. Саблін, Ю. Харламова, А. Шмигальова та інші.

Мета статті - здійснити огляд дискурсного поля проблематики формування державної екологічної політики.

Виклад основного матеріалу. Специфіку діяльності приватних та державних економічних організацій та правових інститутів, а, також, особливостей використання інструментів, які безпосередньо задіяні в процесах реалізації державної політики у сфері захисту довкілля, досліджували такі зарубіжні автори як У.Зирянова, Є. Матвеєва, О. Постановська. Визначенням ключових аспектів імплементації успішного досвіду провідних країн світу щодо реалізації державної політики у сфері захисту довкілля займались такі вчені як: С. Ван Девеєр, Н. Джонстон та Х. Селін. 
Міждисциплінарність як специфічна особливість питань державної політики у сфері захисту довкілля визначає наявність у різних наукових напрямах (економічному, правовому, соціологічному та інших) широкого кола досліджених питань, що, у такому ракурсі, дає змогу зрозуміти природу екологічної політики та основних принципів її успішної реалізації [2, с. 227].

Розглядаючи нинішній стан функціонування нашої держави, можна вказати на збільшення кількості випадків кризових явищ у багатьох сферах життєдіяльності, зокрема, у сфері захисту довкілля, що, з наукової точки таких авторів як: Р. Рудницька та О. Сидорчук, пояснюється незмінними процесами деградації нації, втратою гуманістичних цінностей суспільства, значною різницею у життєвих цілях різних верств населення держави, втратою поваги до суспільних моральних принципів у представників бюрократичної верхівки, високим рівнем бідності тощо.

У такій ситуації, для України необхідною умовою для оптимального функціонування має бути використання ефективних механізмів публічного адміністрування та підвищення результативності здійснення діяльності держави у напрямі захисту довкілля [3].

У ракурсі вітчизняних досліджень сфери захисту довкілля та реалізації державної політики даного напряму, в тому числі, окреслення проблематики публічного адміністрування даної сфери, можна виділити дисертаційні роботи наступних авторів: А. Антонова, Б. Гамалюка, Ю. Горбань, I. Грищенка, В. Демченка, А. Керничної, І. Криничної, В. Крука, О. Лазора, Н. Маєвської, В. Мартиненка, А. Надежденко, О. Настечко, О. Олефіренко, О. Проніної та ін [4, с. 21].

Однак, у наявних на сьогодні наукових дослідженнях авторів вітчизняного та зарубіжного наукових кіл, проблематика публічного адміністрування сфери захисту довкілля та окреслення ефективних напрямів його вдосконалення, у ракурсі проведення активних євроінтеграційних процесів в Україні, розглянуті не досить детально.

3 наукової точки зору Ю. Одума, екологія у процесі свого розвитку як науки дала поштовх до глибокого розуміння значимості саме людської істоти у процесах збереження довкілля та його розумній експлуатації. У такому концепті, на міжнародному рівні було актуалізовано та активізовано розвиток даної науки як обов'язкової умови для подальшого збереження населення Землі та природних ресурсів [5, с. 22].

Значимими у формуванні наукової концепції екологічної політики на теоретичному та практичному рівнях стали дослідження зарубіжного автора Л. Колдуелла, який запропонував основні напрями вдосконалення процесів іiі реалізації на загальнодержавному та регіональному рівнях [6, с. 8].

Аналізуючи спектр наукових робіт, які розкривають різні аспекти реалізації екологічної політики держави, необхідно відзначити доробок таких авторів як: В. Крисаченко та М. Хилько. У науковому доробку визначено, що екологічна культура суспільства $є$ специфічною діяльністю людини, яка направлена на організацію їі життя та перетворень у навколишньому 
середовищі, відповідно до потреб та намірів конкретного індивідуума, a, також, на реалізацію багатьох процесів життєдіяльності об'єктів довкілля.

Л. Юрченко, у свою чергу, акцентує увагу на тому, що екологічна культура визначає основні норми відношень людини i навколишнього середовища та встановлює систему цілей та пріоритетів у суспільному житті, знаходить певне відображення у суспільній свідомості, формах життєдіяльності людей та способів їх життя. На їі думку, мета реалізації екологічної культури полягає у регуляції відносин представників суспільства та різноманітних об’єктів природного середовища на основі комплексу ціннісних установок та орієнтацій. Вона направлена на розвиток природних ресурсів та їх оптимальне відтворення, створює умови для легкого пристосування до змін у навколишньому середовищі.

Необхідно вказати на те, що для формування адекватної екологічної культури важливо впливати на ціннісні орієнтації суспільства, популяризувати знання про екологію у різних іiі аспектах та пропонувати напрями вдосконалення природоохоронної діяльності держави [7, с. 35].

Також, у процесі вивчення політичного виміру вирішення екологічних проблем, науковцями визначено ключові цілі та концепцію реалізації національної екологічної політики, a, також, конкретні засоби для іiі вироблення, та окреслено основні проблеми на шляху до їх ефективного впровадження у життя. $\mathrm{y}$ наукових доробках деяких науковців запропоновано авторське бачення щодо застосування методологічних інструментів з метою оцінювання процесів реалізації екологічної політики держави за критеріями якості, що дозволить встановити рівень ефективності iii впровадження на даний момент часу. У такому концепті розглядається конкретний стан навколишнього середовища, який би задовольняв потреби суспільства (як біологічні, так і соціальні).

На мій погляд, це сприяє формуванню загального уявлення про процеси функціонування державної політики у сфері захисту довкілля, зокрема, використання екосистемного підходу для розв'язання екологічних проблем держави та міждержавного простору, доцільність здійснюваних заходів, 3 економічної точки зору, підтримку балансу між правами та обов'язками суб'єктів екологічних відносин та визначення необхідних умов для соціальної справедливості.

Висновки. Отже, пропонується розглянути ключові етапи історичного розвитку екології як науки та характерних особливостей іï становлення на кожному з них (див. Рис. 1) 


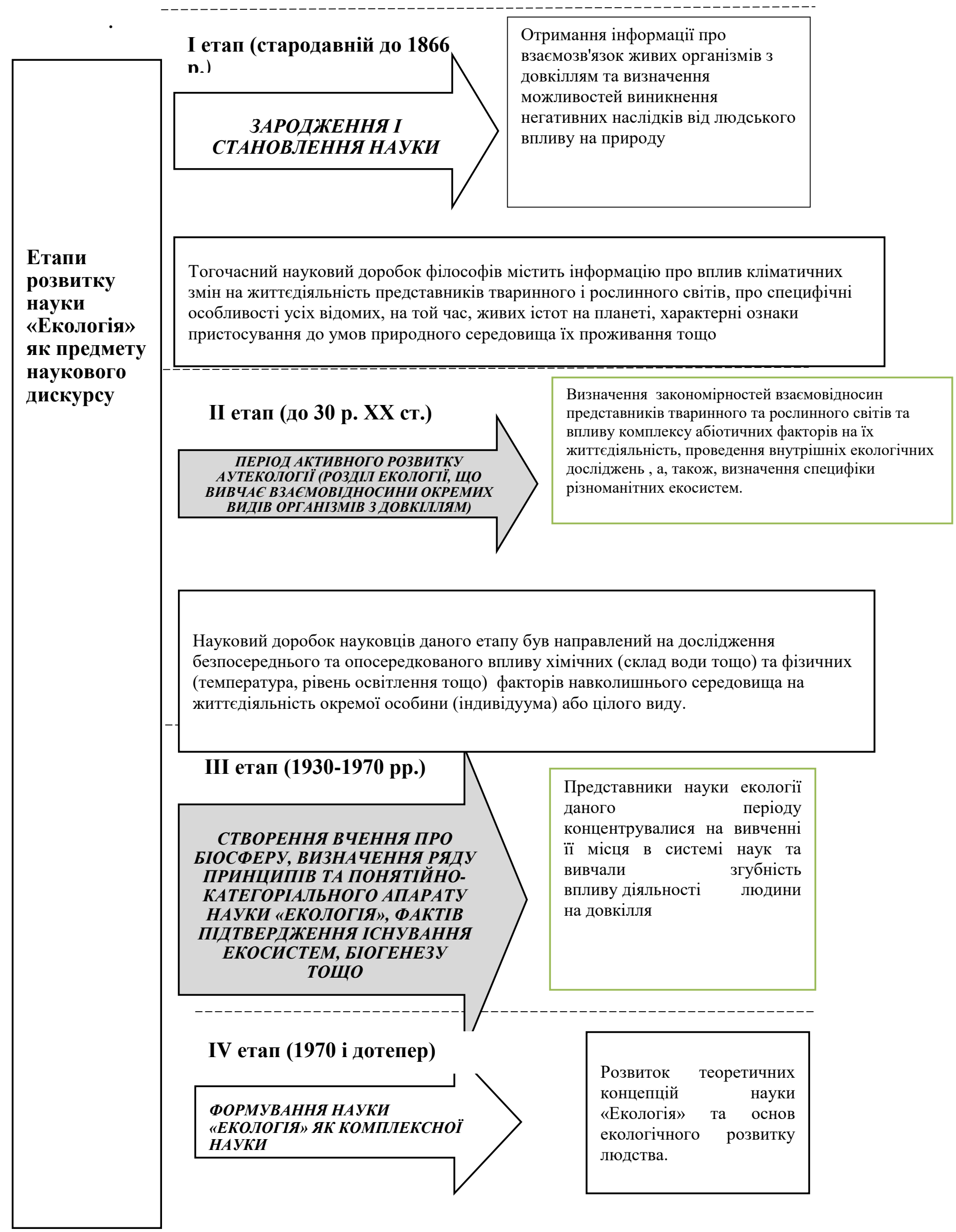

Puc. 1. Етапи розвитку науки екології як предмету наукового дискурсу 


\section{Лimepamypa:}

1. Дуюнова Т.В. / ЩОДО ПОНЯТТЯ ТА ЗМІСТУ ЕКОЛОГІЧНОЇ ПОЛІТИКИ УКРАЇНИ Матеріали Міжнародної науково-практичної конференції «Молодь і технічний прогрес в АПВ». - 2020, с. 274-275 http://dspace.khntusg.com.ua/bitstream/ $123456789 / 12290 / 1 / 162 . p d f$

2. Венка-Вєдєнкіна П. Д. тЕОРЕтИЧНі ЗАсАДИ сУЧАсНОЇ ЕКОЛОГіЧНОЇ ПОЛітИКИ Міжнародні та політичні дослідження. 2019. Вип. 32. С.225-244

3. Омаров А. Е. Механізми формування та реалізація державної політики екологічної безпеки України. Дисертація на здобуття наукового ступеня доктора наук з державного управління за спеціальністю 25.00.05 - «Державне управління в сфері державної безпеки та охорони громадського порядку», Національний університет цивільного захисту України, Харків, 2019., 421 с.

4. Тішкова Н.Л. Реформування державного управління охороною навколишнього середовища в контексті європейської інтеграції України. Дисертація на здобуття наукового ступеня доктора наук з державного управління за спеціальністю 25.00.01-теорія та історія державного управління. Дніпропетровський регіональний інститут державного управління Національної академії державного управління при Президентові УкраїниДніпро 2018 р., С.265.

5. Гаєвський І.В. Механізми формування та реалізації державної екологічної політики в умовах сталого розвитку. Рукопис. Дисертація на здобуття наукового ступеня кандидата наук 3 державного управління за спеціальністю 25.00 .02 - механізми державного управління. Інститут підготовки кадрів державної служби зайнятості Україіни. Київ, 2020. Стр 224.

6. Ніколаєв К. Д. ДИПЛОМНА РОБОТА ВИПУСКНИКА ОСВІТНЬОГО СТУПЕНЯ «МАГІСТР» За освітньо-професійною програмою «Менеджмент в органах публічного управління» Тема: «Механізми реалізації державної екологічної політики в Україні» НАЦІОНАЛЬНИЙ АВІАЦЙНИЙ УНІВЕРСИТЕТ НАВЧАЛЬНО-НАУКОВИЙ ІНСТИТУТ НЕПЕРЕРВНОЇ ОСВІТИ Кафедра публічного управління та адміністрування Київ 2020, 95 с.

7. Логвиненко В. М. Теоретичні основи феномену екологічної культури / В. М. Логвиненко // Вісник Національного технічного університету України "Київський політехнічний інститут". Філософія. Психологія. Педагогіка. - 2011. - № 3. - С. 34-38. Режим доступу: http://nbuv.gov.ua/UJRN/VKPI_fpp_2011_3_6

\section{References:}

1. Duiunova T.V. (2020). Shchodo poniattia ta zmistu ekolohichnoi polityky Ukrainy [On the concept and content of environmental policy of Ukraine]. Molod i tekhnichnyi prohres $v$ APV Materialy Mizhnarodnoi naukovo-praktychnoi konferentsii - Youth and technical progress in $A P V$ : Proceedings of the International scientific-practical conference. (pp. 274-275). Kharkiv Petro Vasylenko National Technical University of Agriculture. Retrieved from http://dspace.khntusg.com.ua/bitstream/123456789/12290/1/162.pdf [in Ukrainian].

2. Venka-Viedienkina, P. D. (2019). Teoretychni zasady suchasnoi ekolohichnoi polityky [Theoretical fundamentals of modern environmental policy]. Mizhnarodni ta politychni doslidzhennia - International and political research, 32, 225-244 [in Ukrainian].

3. Omarov, A. E. (2019). Mekhanizmy formuvannia ta realizatsiia derzhavnoi polityky ekolohichnoi bezpeky Ukrainy [Mechanisms of formation and implementation of state policy of environmental safety of Ukraine]. Doctor's thesis. Kharkiv: Natsionalnyi universytet tsyvilnoho zakhystu Ukrainy [in Ukrainian].

4. Tishkova, N.L. (2018). Reformuvannia derzhavnoho upravlinnia okhoronoiu navkolyshnoho seredovyshcha $\mathrm{v}$ konteksti yevropeiskoi intehratsii Ukrainy [Reforming public administration of environmental protection in the context of Ukraine's European integration]. 
Doctor's thesis. Dnipro: Dnipropetrovskyi rehionalnyi instytut derzhavnoho upravlinnia Natsionalnoi akademii derzhavnoho upravlinnia pry Prezydentovi Ukrainy [in Ukrainian].

5. Haievskyi, I.V. (2020). Mekhanizmy formuvannia ta realizatsii derzhavnoi ekolohichnoi polityky $\mathrm{v}$ umovakh staloho rozvytku [Mechanisms of formation and implementation of the state ecological policy in the conditions of sustainable development]. Doctor's thesis. Kyiv: Instytut pidhotovky kadriv derzhavnoi sluzhby zainiatosti Ukraiiny [in Ukrainian].

6. Nikolaiev, K. D. (2020). Mekhanizmy realizatsii derzhavnoi ekolohichnoi polityky v Ukraini [Mechanisms of implementation of the state environmental policy in Ukraine]. Master's thesis. Kyiv: Natsionalnyi Aviatsiinyi Universytet Navchalno-Naukovyi Instytut Neperervnoi Osvity [in Ukrainian].

7. Lohvynenko, V. M. (2011). Teoretychni osnovy fenomenu ekolohichnoi kultury [Theoretical foundations of the phenomenon of ecological culture]. Visnyk Natsionalnoho tekhnichnoho universytetu Ukrainy "Kyivskyi politekhnichnyi instytut". Filosofiia. Psykholohiia. Pedahohika - Bulletin of the National Technical University of Ukraine "Kyiv Polytechnic Institute". Philosophy. Psychology. Pedagogy, 3, 34-38. Retrieved from http://nbuv.gov.ua/UJRN/VKPI_fpp_2011_3_6 [in Ukrainian]. 